\title{
Jon Verriet
}

Independent Researcher

\section{Ready Meals and Cultural Values in the Netherlands, 1950-1970}

\begin{abstract}
Dutch food history is often limited to descriptions of socioeconomic circumstances and food practices. Much can be gained from examining the impact of cultural values on consumption. Among such values are inhibitions regarding convenience and a great concern for nutrition and health, two features that influenced the popularity of ready meals in the Netherlands during the 1950s and 1960s, despite manufacturers' efforts. These canned, jarred, freeze-dried and frozen products suffered the consequences of a requirement imposed on housewives: carefully prepared, nutritious meals for their families, day in, day out.
\end{abstract}

\author{
Keywords \\ Ready Meals \\ Cultural Values \\ Food Choice \\ Convenience Food \\ Cultural History \\ Housewife \\ Nutrition \\ The Netherlands \\ Canned Food \\ Frozen Food
}

\section{Introduction}

In the Netherlands, food history has generally been written by historians whose assessments are informed by distinct socio-economic or technological approaches. ${ }^{1}$ Others, such as ethnologists, have focused on food practices, but also took note of socio-economic and technological influences. ${ }^{2}$ However, the cultural (or psychological) aspect has been somewhat neglected. "Cultural values" is used broadly here, as a term signifying perceptions, mentalities or opinions that relate to, and influence, food preparation and consumption. An example of the influence of cultural values on foodways is the conscious

1 Stephen J. MENNEll, Anne MURCOTT, Anneke H. VAN OTTERloO, Peter SCHOLLIERS, "Eight Contributions to Social Food Studies in the Low Countries", Appetite, vol. 45 (2005), p. 2.

${ }^{2}$ An example is the work of Jozien Jobse-van Putten and other scholars affiliated with the Meertens Institute. 
abstention of Catholics on Fridays, when eating meat was not permitted by the rules of their faith (a practice that continued well into the twentieth century in the Netherlands). Such cultural values have remained a side issue in Dutch food historiography. When authors point out certain norms, values or perceptions vis-á-vis food, they are mentioned briefly without argument or reference. ${ }^{3}$ Researching such factors has often been of interest to anthropologists, sociologists, and food scientists, who have focused on psychological preferences when conducting work on contemporary societies and their relation to food. ${ }^{4}$ But even internationally, relatively few scholars seem interested in historically examining psychological determinants of food choice. ${ }^{5}$ Perhaps historians are hesitant because such bygone, intangible cultural values are not easy to research or to concretise. The purpose of this article, then, is not to trivialise the importance of socio-economic, technological or practical factors as explanations of food selection and consumption. It is merely an attempt at creating space for cultural factors in these explanations by examining the influence cultural values have (had) on food choice.

Such a focus on cultural values can help understand past and present-day consumption patterns. Socio-economic explanations often focus on financial determinants, whereas technological frameworks address production possibilities for certain goods. Consumers, though, are influenced by more than just financial or technological possibilities. These explanations also do not account for consumers who refused to buy certain products, (temporarily) rejecting the "progress" of their foodways. The imagery surrounding a product, influenced by consumers' worries and hopes, matters greatly. Additionally, the approach mentioned can work the other way around as well, refining one's understanding of certain societal trends through food choice. For example, one might gain insight into second-wave feminism by examining 1960s attitudes towards cooking.

\footnotetext{
${ }^{3}$ There are some notable exceptions to this rule, such as: Marlou SCHROVER, Inge MESTDAG, Anneke H. VAN OTTERLOO, Chaja ZEEGERS, "Lekker. Waarom Knoflook Niet Meer Vies Is" [Tasty. Why Garlic is No Longer Considered Gross], in Isabel HOVING, Hester DIBBITS, Marlou SCHROVER (eds), Veranderingen van het Alledaagse: Cultuur en Migratie in Nederland [Changes in Everyday Life: Culture and Migration in the Netherlands] (The Hague, 2005), pp. 77-112; Annemarie DE KNECHT-VAN EEKELEN, Marianne STASSE-WOLTHUIS (eds), Voeding in onze Samenleving in Cultuurbistorisch Perspectief [Nutrition in our Society from a Cultural-Historical Perspective] (Alphen aan de Rijn, 1987).

${ }^{4}$ Examples (among many others) are: Anne MURCOTT (ed.), The Sociology of Food and Eating: Essays on the Sociological Significance of Food (Aldershot, 1983); John GERMOV, Laura WILLIAMS (eds), A Sociology of Food and Nutrition: The Social Appetite (Oxford, 2000); Lynn FREWER, Hans VAN TRIJP (eds), Understanding Consumers of Food Products (Cambridge, 2007).

${ }^{5}$ Exceptions include work by an anthropologist and a sociologist: Sidney W. MINTZ, Tasting Food, Tasting Freedom: Excursions into Eating, Culture, and the Past (Boston, MA, 1996); Alan WARDE, Consumption, Food \& Taste: Culinary Antinomies and Commodity Culture (London, 1997).
} 
This article examines two specific cultural values that had an influence on the popularity of ready meals sold in the Netherlands during the 1950s and 1960s. First, certain inhibitions regarding convenience lingered: strong feelings among the Dutch populace about the duties of a housewife facilitated the idea that only a bad housewife refused to cook, even for one day. Secondly, the influence that a discourse on vitamins had on food consumption, before and after the Second World War, combined with the ever-growing importance of nutritional value and healthy choices. The genesis of these two cultural values will be examined, as well as their influence on consumption choices.

The ready meal forms the case study for this paper, and the period of interest runs roughly from 1950 to 1970 . A "ready meal" is defined as a product to which the consumer does not need to add anything, and that only needs heating before use. As a main dish consisted of a staple food with meat and vegetables to most Dutch people, some products did not qualify as a whole meal (a can containing just meat and sauce, for instance). Therefore the term "ready meal" refers here to the most extreme form of convenience food: the housewife did not have to add anything to the product - unless she wanted to.

To examine the cultural values surrounding ready meals, advertisements and articles from the magazines Margriet and Libelle have been used. A survey from the year 1962 reported that $53 \%$ of all women from the age of 15 (and $35 \%$ of all men) read Margriet, and that its readers were remarkably similar to the average Dutch woman when it came to age, religion, and income. ${ }^{6}$ Such research is not available for Libelle, but since this publication also boasted impressive circulation figures, one can conclude that together, these magazines represented a significant part of Dutch society. ${ }^{7}$ Hence one can attempt to carefully glean some of the cultural values prevalent in the Netherlands from such magazines, as others have done before. ${ }^{8}$

Five full years of the two aforementioned magazines have been examined: the volumes 1950, 1955, 1960, 1965, 1970. From 1955 onwards, 26 different ready meals were advertised by five different manufacturers: Conimex, Koenvisser, Norica, Olba, and Ras. Together they came up with 47 different

\footnotetext{
${ }^{6}$ Margriet Lezerskringonderzoek - Dl. 1 Algemene Analyse van de Lezerskring [Margriet Readership Survey - Pt. 1 General Analysis of the Readership], Attwood Statistics; Dutch Dep. (Amsterdam, 1962), passim.

${ }^{7}$ Libelle claimed to have 600.000 subscribers in the year 1950, and printed 532.283 copies per week in the year 1967, which made it the second biggest women's magazine in the Netherlands after Margriet. Libelle, 12-29-1950 (\#52), p. 25; Angelie P. G. SENS, Van Zeep tot Soap: Continuïteit en Verandering in Geillustreerde Vrouwentijdschriften [From Soap to "Soap": Continuity and Change in Illustrated Women's Magazines] (Amsterdam, 2004), p. 45.

${ }^{8}$ Among others: Christine D. A. BRINKGREVE, Michel KORZEC, "Margriet Weet Raad": Gevoel, Gedrag, Moraal in Nederland 1938 - 1978 ["Margriet Offers Help": Sentiments, Behavior and Morals in the Netherlands 1938 - 1978] (Utrecht, 1978); Trude C. M. KNIJN, Carla M. L. H. VERHEIJEN, Moederschap in een Vrouwenblad: Van Opoffering naar Zelf-ontplooiing [Motherhood in a Women's Magazine: From Sacrifice to Self-Development] (Nijmegen, 1982).
} 
Table 1: Advertisements for ready meals in Margriet and Libelle.

\begin{tabular}{lllllll}
\hline Brand & $\begin{array}{l}\text { Adverts } \\
\text { in } \mathbf{1 9 5 5}\end{array}$ & $\begin{array}{l}\text { Adverts } \\
\text { in } \mathbf{1 9 6 0}\end{array}$ & $\begin{array}{l}\text { Adverts } \\
\text { in } \mathbf{1 9 6 5}\end{array}$ & $\begin{array}{l}\text { Adverts } \\
\text { in } \mathbf{1 9 7 0}\end{array}$ & $\begin{array}{l}\text { Variety of } \\
\text { adverts }\end{array}$ & $\begin{array}{l}\text { Variety of } \\
\text { products }\end{array}$ \\
\hline Conimex & 17 & 12 & 2 & 15 & 8 & 3 \\
Olba & 10 & - & - & - & 6 & 3 \\
Koenvisser & - & 18 & 24 & 24 & 26 & 7 \\
Ras & - & 8 & - & - & 4 & 4 \\
Norica & - & - & 5 & - & 3 & 5 \\
\hline
\end{tabular}

advertisements, greatly varying in colour, size, and message. Some, especially those by Conimex and Olba during the 1950s, were quite small (a sixth or an eighth of a page) and in black and white. Later advertisements in colour could often take up an entire page. The companies published a total of 135 advertisements focused on ready meals. The lion's share of these adverts came from either Conimex or Koenvisser: 112 in total (see table 1).

Advertisements for other food products have also been analyzed for this paper. The content of the magazines was further explored by paying special attention to weekly columns and the section on cooking (on average two full pages per week for both magazines).

There are various perceptions that play a role when deciding to buy a processed product such as the ready meal. Two of these values will be discussed, but for now one can imagine these dishes to have a complex image in the public's eye, which means that buying canned spaghetti or frozen pilaf said more about one's cultural values towards food than buying a potato or cabbage. Since these products were charged with meaning, they lend themselves particularly well for examining cultural values, thereby making them a good fit for a study dealing with food choice from a cultural historian's perspective. There is a simpler reason for examining ready meals as well: historical research on these products is rare, both in the Netherlands and elsewhere. While sociologists and nutritionists have shown some interest in studying convenience foods, ${ }^{9}$ the articles and books written by food historians do not feature the ready meal in anything but a minor supporting role.

The economic impact of the cultural values under consideration on the sale of ready meals sadly remains unclear. Obtaining sales records for these products has proved to be impossible; such information manufacturers cannot or will not share. Conclusions about the influence of these values on the

\footnotetext{
${ }^{9}$ For some examples see: Mary-Ellen WALES, "Understanding the Role of Convenience in Consumer Food Choices: A Review Article", Studies by Undergraduate Researchers at Guelph, vol. 2 , no. 2 (2009).
} 
popularity of ready meals can therefore only be estimated. However, in a way the proof of the pudding is in the eating. If the reader is fully convinced of the pervasiveness of the mentioned inhibitions regarding convenience and the intense stress laid on nutrition, then concluding that these must have had a marked influence on the popularity of ready meals seems justifiable.

\section{A Long-Term View}

Food consumption had changed greatly since the nineteenth century, a time in which the average Dutch family grew its own crops and mainly ate potatoes. After the Industrial Revolution, which started in the 1860s, and the urbanisation that accompanied it, many households were no longer able to produce their own food. Norbert Elias points out an interesting paradox: "The same process which has made people less dependent on the vagaries of nature has made them more dependent on each other". ${ }^{10}$ Stores quickly gained in size and product variety during the twentieth century, especially in the post-war years, when new products arrived almost daily. ${ }^{11}$ Multinationals like Heinz and Nestlé were rapidly diversifying their products. It is no wonder that some food historians contend that the most essential development of the twentieth century was the switch from scarcity to abundance, ${ }^{12}$ an evolution that accelerated greatly from the 1950 s onwards. To get the population to notice all these new food products, companies started advertising more in women's magazines such as Margriet and Libelle. ${ }^{13}$ The target of all these cheerful images and texts was the housewife, purported to be solely responsible for the (smaller) purchases within the household. Marketing specialists refined advertisements, claiming that women were to be persuaded by playing on their feelings of guilt and pride rather than rational arguments.

${ }^{10}$ Norbert ELIAS, Involvement and Detachment (Oxford, 1987), p. 10.

${ }^{11}$ By 1970, there were 700 supermarkets in the Netherlands. Ileen MONTIJN, Aan Tafel! Vifftig Jaar Eten in Nederland [Dinner's Ready! Fifty Years of Eating in the Netherlands] (Utrecht, 1991), p. 50 .

12 Anneke H. VAN OTTERLOO, Eten en Eetlust in Nederland (1840-1990): Een HistorischSociologische Studie [Eating and Appetite in the Netherlands (1840 - 1990): A Historical-Sociological Study] (Amsterdam, 1990), p. 257.

${ }^{13}$ In 1952 there were on average 9 food adverts in a volume of Margriet; in 1964 this number had risen to 20.3; in 1970 it went back to 19.9 . In percentages: $4.1 \%$ in $1952 ; 11 \%$ in $1965 ; 12.1 \%$ in 1971. Rob PIKAAR, "Dàt is Gezonde Voeding. Iedere Dag uit Ieder Vak.": De Invloed van de Voedingsvoorlichting op de Reklame in Margriet in de Periode 1950-1975 "Now Thát is Healthy Food. Every Day from Every Section": The Influence of Nutrition Education on the Advertisements in Margriet During the Years 1950 - 1975] (Rotterdam, 1995; unpublished thesis), p. 55. 
The improvement of preservation techniques was a prerequisite for the further development of ready meals during the 1950s and 1960 s. ${ }^{14}$ After all, ready meals were preserved foods, whether they were canned, jarred, freezedried or frozen. The canning industry developed rather late in the Netherlands, which meant that the popularity of canned goods rose quickly just after the Second World War. ${ }^{15}$ A significant drop in prices meant that most households were able to try beans, peaches or ready meals from a can in post-war decades. Frozen foods, however, remained a curiosity in the Netherlands of the 1950s. Whereas a large number of U.S. citizens owned refrigerators (and often even freezers) before the Second World War, ${ }^{16}$ the situation in the Netherlands was quite different. Even after the war most Dutch families owned neither of these appliances. ${ }^{17}$ Production, transportation and storage costs remained high, which meant steep prices for consumers. Fresh greens simply remained cheaper. Only when the government abandoned its wage restricting policies during the 1960s, the number of households possessing a freezer quickly increased. By 1965, Iglo (the Netherlands' biggest producer of frozen foods) offered seven different frozen meals. ${ }^{18}$

The principal condition for the popularity of new products was a spectacular rise in the purchasing power of the Dutch population during the 1950s and (especially) the 1960s. Price became less important as a determinant of food choice. In fact, although the population at large spent an increasing amount of money on food, the relative expenses decreased greatly. While $70 \%$ of income was spent on food in 1850, this percentage dropped to $39 \%$ in 1950 and even

\footnotetext{
${ }^{14}$ Ready meals were no longer a novelty in these decades. They were sold in the Netherlands before the Second World War, and had in fact existed in Europe since (at least) 1851. Stuart THORNE, The History of Food Preservation (Cumbria, 1986), p. 56.

15 Anneke H. VAN OTTERLOO, "Prelude op de Consumptiemaatschappij in Voor- en Tegenspoed 1920-1960" [Prelude to Consumerism, in Prosperity and Hardship 1920 - 1960], in: Johan W. SCHOT et al. (eds), Techniek in Nederland in de Twintigste Eeuw. Vol. III: Landbouw, Voeding [Technology in the Netherlands during the Twentieth Century. Vol. III: Agriculture, Nutrition] (Zutphen, 1998-2003), p. 276.

${ }^{16}$ Between $80 \%$ to $90 \%$ of the population of the U.S. owned a refrigerator around 1950 . Kenneth F. KIPLE, A Moveable Feast: Ten Millennia of Food Globalization (Cambridge, 2007), pp. 234-235.

17 The percentages for refrigerator possession in the Netherlands: $2 \%$ in 1947; $10 \%$ in 1960 ; 93\% in 1984. Anneke H. VAN OTTERLOO, Eten en Eetlust..., p. 175; Hans BUITER, "Koelen en Vriezen" [Refrigeration and Freezing], in: Johan W. SCHOT et al. (eds), Techniek in Nederland..., p. 350. In 1980 only 49\% of Dutch households owned a freezer. Anneke H. VAN OTTERLOO, Babette SLUYTER, "Naar Variatie en Gemak 1960-1990" [Towards Variation and Convenience 1960 - 1990], in: Johan W. SCHOT et al. (eds), Techniek in Nederland..., p. 293.

${ }^{18}$ Iglo price list 1965, Historical Archive Unilever, Rotterdam (henceforth HUAR). The Iglo price lists have been scanned and are stored in the digital archive of Unilever, which is a part of their historical archive set in Rotterdam. They were available upon request, and hence still reside with the author for those interested. The material lacked a specific codification. They contain the manufacturer's suggested retail price for Iglo products at the time.
} 
Table 2: Gross National Income Per Capita.

\begin{tabular}{ll}
\hline Year & Gross National Income (converted to euro of 2011) \\
\hline 1950 & 848 \\
1955 & 1273 \\
1960 & 1673 \\
1965 & 2547 \\
1970 & 4569 \\
\hline
\end{tabular}

Source: 111 Jaar Statistiek in Tijdreeksen, 1899-2010, CBS, pp. 8, 86-89.

Table 3: Prices of staple foods 1950-1970.

\begin{tabular}{llll}
\hline Year & \multicolumn{3}{l}{ Price per kilo (converted to euro) } \\
\cline { 2 - 4 } & Potatoes & Bread & Rice \\
\hline 1950 & 0.07 & 0.17 & 0.46 \\
1960 & 0.11 & 0.20 & 0.45 \\
1970 & 0.21 & 0.36 & 0.83 \\
\hline
\end{tabular}

Source: 111 Jaar Statistiek in Tijdreeksen, 1899-2010, CBS, pp. 179184. Prices in 2009: Potatoes $€ 0.72$; Bread $€ 1.46$; Rice $€ 2.03$.

further to $20 \%$ in $1971 .{ }^{19}$ The upsurge of the Gross National Income during the post-war decades is rather remarkable (see table 2).

In judging the affordability of ready meals during these years, it might be useful to look at the prices of some staple foods (table 3). Considering the fact that a can of Conimex nasi goreng ${ }^{20}$ (two portions) cost $€ 0.95$ (converted to fixed euro) in 1955, and its frozen variety, made by Iglo, $€ 1.10$ in 1965, it seems clear that these meals were relatively expensive, especially during the 1950 s. $^{21}$ In 1955 it was quite easy to compose a four-person dinner that was cheaper than $€ 1.90$, the cost of two cans of Conimex' nasi goreng.

19 Anneke H. VAN OTTERLOO, "Voeding in Verandering" [Changing Foodways], in: Johan W. SCHOT, et al. (eds), Techniek in Nederland..., p. 241; Catherine SALZMAN, "Margriet's Advies aan de Nederlandse Huisvrouw. Continuïteit en Verandering in de Culinaire Geschiedenis van Nederland 1945-1975" [Margriet's Advice to the Dutch Housewife. Continuity and Change in the Culinary History of the Netherlands 1945 - 1975], Volkskundig Bulletin, vol. 11 (1985), p. 23.

${ }^{20}$ Nasi goreng is a spicy dish which consists of fried rice. Immensely popular in the Netherlands, the meal epitomises Indonesian cuisine for a large part of the Dutch population, although its true origins are far more complicated. "Indonesian" cuisine was known before the war, but significantly gained in popularity during the 1950s. In Bami (or bahmi) goreng the rice is swapped for noodles.

${ }^{21}$ Conimex price: Margriet, 7-16-1955 (\#29), p. 11; Libelle, 7-16-1955 (\#29), p. 87. Iglo price: Iglo price list 1965, HUAR. 
However, table 2 shows that in regard to ready meals, the purchasing power of households increased greatly. As shown above, the Gross National Income per capita increases by $79.3 \%$ in the latter half of the 1960 s, while the price of an Iglo nasi goreng frozen meal only rises by $18.8 \%$ (from $€ 1.10$ to $€ 1.30$ ) in that same period. ${ }^{22}$ The price of canned ready meals is even steadier throughout these decades. A can of nasi goreng, produced by Koenvisser, sold at $€ 0.72$ in $1960 .{ }^{23}$ Five years later, the can's price has only increased by $€ 0.05,{ }^{24}$ while the Gross National Income per capita increased by no less than $52.2 \%$ during that same period. If the price of these cans had been fixed to the rise in income, they would have cost $€ 1.97$ by 1970 , almost double their actual price. ${ }^{25}$

For the majority of the population, the rising prosperity in the Netherlands created more space for cultural values to play a role when buying food. Now, ready meals would not be dismissed because of their price. While foodways had previously expressed various social and religious identities in significant ways, such as certain dietary restrictions among Christians, the possibilities to project one's individual identity on a consumption pattern greatly increased when society as a whole became more affluent. ${ }^{26}$ While food production, advertisements and consumption were almost made into psychological experiments by marketers and advertisers, the condition for this change was an increase in purchasing power. Questions that are inconceivable in a society of scarcity were now being asked: can a housewife skip a day of cooking and open up a can? Is frozen spinach healthier than jarring one's own vegetables?27 Stephen Mennell has called this the "civilising of appetite": now that there was a choice, people had to choose. ${ }^{28}$ In the post-war Netherlands, food choice became more influenced by cultural values than ever before. ${ }^{29}$

One of the factors influencing food choice, which became increasingly relevant throughout the twentieth century, is taste. Partly a cultural value in itself, partly biologically determined, taste is a difficult concept to approach historically.

22 Iglo price lists of 1965 and 1970, HUAR.

${ }^{23}$ Margriet, 4-2-1960 (\#14) p. 69; Libelle, 4-16-1960 (\#16), p. 87.

${ }^{24}$ Margriet, 1-9-1965 (\#2) p. 15.

${ }^{25}$ Which was $€ 1.00$. Margriet, 4-4-1970 (\#14), p. 168; Libelle, 4-4-1970 (\#15), p. 45.

${ }^{26}$ AnnekeH.VANOTTERLOO,Etenen Eetlust...,p.258.Seealso:SidneyMINTZ, TastingFood...; Peter SCHOLLIERS, "Novelty and Tradition. The New Landscape for Gastronomy", in: Paul H. FREEDMAN, Food: The History of Taste (Berkeley, CA, 2007), p. 337.

${ }^{27}$ Religious values were an exception. Their importance in the determination of the food pattern of Dutch nationals slowly receded during post-war decades. Jozien JOBSE-VAN PUTTEN, Eenvoudig maar Voedzaam: Cultuurgeschiedenis van de Dagelijkse Maaltijd in Nederland [Plain but Nutritious: A Cultural History of the Daily Meal in the Netherlands] (Nijmegen, 1996), p. 410.

${ }^{28}$ Stephen J. MENNELL, "On the Civilizing of Appetite", Theory, Culture \& Society, vol. 4 (1987) p. 398.

${ }^{29}$ Anneke van Otterloo puts it a little differently: "The field of food and food preparation has slowly become a matter of morals, ideology and science and less a matter of pure survival". Anneke H. VAN OTTERLOO, Eten en Eetlust..., p. 258. 
Some contemporary sources suggest that 1950 s and 1960s ready meals had unsatisfactory organoleptic (sensory) features. ${ }^{30}$ In a survey of 1968 a tasting panel judged Iglo frozen meals quite harshly, calling them "overcooked and too soft", "dry", "stringy", and "weak". 31 Apart from such qualities, the cultural values discussed below were also, in a way, taste-determining mentalities. Food choice was now influenced by much more than just price or technological limitations, and manufacturers of ready meals needed to take this into serious consideration.

\section{Inhibitions regarding convenience}

First, the inbibition towards convenience prevalent during the 1950s and 1960s will be examined. The advertisements found in women's magazines Margriet and Libelle can be seen as half of the conversation between a company and its clientele. The message of the advert is never entirely top-down; it takes into account the potential expectations and wishes of the customer. One can imagine that an advertisement stressing the safety of a product is actually responding to certain concerns among consumers. This does not mean that marketers attempt to fully mirror the values of the customer, but they do very much take them into consideration, hence one can carefully distil the feelings and worries of the population from these adverts. The relation between the consumer and the producer is not a zero-sum game. ${ }^{32}$ Both benefit from attractive high-quality products entering the market, making advertisements part of the negotiation between these two parties. ${ }^{33}$

${ }^{30}$ Emile W. HELLENDOORN, "Een Nieuw Droog Vlugkokend Gebakken Rijstprodukt" [A New Dried Parboiled Baked Rice Product], Conserva, vol. 16 (1967), p. 1.

${ }^{31}$ M. A.VAN DER MEER,J.B. LASSCHE, C.N.PASCHA,Diepuriesmaaltijden:Voedingswaarde en Organoleptische Kwaliteiten van Diepvriesmaaltijden en de Invloed van Enige Verwarmingsmethoden op deze Eigenschappen [Frozen Meals: Nutritional Value and Organoleptic Qualities of Frozen Meals and the Influence of Certain Heating Methods on these Attributes] (Wageningen, 1968), pp. 15-16. The grades are on page 32. The meals score lowest on both structure and taste. All quotes taken from sources that carry Dutch titles, along with all articles and advertisements in Margriet and Libelle, have been translated by the author.

${ }^{32}$ Food adverts in the 1950s and 1960s are, by the way, mostly aimed exclusively at women, causing Jan van Lieshout to conclude that in adverts "the customer was not king, but queen". Jan VAN LIESHOUT, Het Kan Wel op al is het Lekker. Het Dagelijks Leven van Kleine man tot Jan Modaal Zichtbaar Gemaakt in 50 jaar Reclame [Although It's Tasty, Sometimes It's Enough. The Daily Life of the "Little Guy" and "John Smith" Visualized in 50 Years of Advertisements] (Bussum, 1980), p. 49.

33 This might seem somewhat comparable to Michel de Certeau's theoretical construction of producer (strategy) and consumer (practice). For De Certeau, however, the division between consumer and producer is static: the costumer is a receiver who can only start to make something out of the advert (almost literally) after it has been conceived and designed. While De Certeau sees more of a deadlock, a situation which can be described as strategy versus practice, this article works with the idea of an essential influence of the consumer on the production process. See: Michel DE CERTEAU, The Practice of Everyday Life (Berkeley, CA, 1988), p. XII. 
During the 1950s, most women were fully occupied at home with doing laundry, cooking, and taking care of children. In 1947 only 10\% of all married women in the Netherlands worked for a wage and outside the home; in 1960 this rate had fallen to $7 \% .{ }^{34}$ The division of labour within the household was clear, making the working week of a housewife long and arduous. Els Kloek writes:

The demands made towards the housewife, both materially and emotionally, reached a level which humanity had not dared to dream of before. The rooms had never been this clean, the clothes had never been this proper, the meals had never been so lovingly prepared, the house had never been this cosy, $[\ldots]$ and the attention towards the welfare of the children had never reached such a high standard as it had in the second half of the twentieth century. More precisely: the standard had never been this high. ${ }^{35}$

Although her tasks added up to a full-time job, the housewife received an immense amount of appreciation for all her hard work. Magazines such as Libelle and Margriet commended her: a pat on the back for these soldiers of the household!

According to Kloek, the high regard for a clean house and a proper daily meal was a typical offshoot of "bourgeois values": order and respect for authority, a decent work ethic, thrift and self-restraint. ${ }^{36}$ Those who helped rebuild the Netherlands without a fuss were seen as silent heroes. This meant that Dutch women put a lot of time and effort into taking care of their families. In 1964 the housewife claimed she spent 515 minutes a day on her various tasks, of which 150 minutes were taken up by meal preparation. ${ }^{37}$

It seems many Dutch women were content with their tasks. In an anonymous survey of 1964, $80 \%$ of Dutch housewives reported being either "happy" or "really happy", and $82 \%$ of them said that meeting their daily responsibilities gave them a lot of pleasure. ${ }^{38}$ Women's magazines were right by their side,

${ }^{34}$ Els M. KLOEK, Vrouw des Huizes: Een Cultuurgeschiedenis van de Hollandse Huisvrouw [Lady of the House: A Cultural History of the Dutch Housewife] (Amsterdam, 2009), p. 195. 19\% of the total female labour force worked in 1971. Hettie A. POTT-BUTER, Kea G. TIJDEN, Janneke PLANTENGA, Angelique JANSSENS, "Beroepsarbeid van Vrouwen en Mannen" [Professional Labour of Women and Men], in: Hettie A. Pott-Buter, Kea G. Tijdens (eds), Vrouwen: Leven en Werk in de Twintigste Eeuw [Women: Life and Work in the Twentieth Century] (Amsterdam, 1998), pp. 150-151.

${ }^{35}$ Els M. KLOEK, Vrouw des Huizes..., p. 212.

36 Ibid., p. 181.

${ }^{37}$ De Nederlandse Huisvrouw: Op Weg Naar het Jaar 2000 [The Dutch Housewife: Towards the Year 2000], Survey commissioned by Aselect (Amsterdam, 1985), p. 25.

${ }^{38}$ For 1964: 29\% is "very happy", 51\% "happy" and 16\% "moderately happy". These may partly have been attempts at giving desirable answers. The 1964 answers to "Do you like your work [around the house]?": $32 \%$ called it "thoroughly enjoyable", 50\% said "very enjoyable", $14 \%$ said "moderately enjoyable”. Ibid., pp. 136, 144. 
portraying the housewife and mother in her ideal form. ${ }^{39}$ In a study on motherhood as portrayed in magazines, Trude Knijn and Carla Verheijen describe this ideal as follows: "Because of her determination and courage, thinking of everyone but herself, she is able to provide her family with love and care [...] The mother-type is the same in all of these articles, a woman serving her family and gladly performing her tasks with love". ${ }^{40}$ Having read all editions from 1960 of Margriet and Libelle, Knijn and Verheijen conclude that the image of motherhood can only be summed up by one word: "sacrifice". 41

As mentioned, housewives spent an average of 150 minutes a day on meal preparation. Furthermore, in 1964 a large majority (75\%) said cooking was one of their favourite tasks. ${ }^{42}$ Perhaps this was partly the case because their audience (husband and children) proved appreciative when dinner was appetising and nutritious, sometimes causing them to go the extra mile in the kitchen. It seems the latter was not necessarily a Dutch phenomenon. ${ }^{43}$ Preparing a meal was typically a woman's task, making cooking a gendered concept. ${ }^{44}$ Most men were helpless when confronted with cooking appliances, in part because they had not been raised with the idea that they would ever have to make their own meals. Libelle illustrates the dependency of the average husband:

When his wife is feeling well, a cosy breakfast awaits him in the morning, and all is not so bad. But when she's nauseous or tired, then the poor fellow rushes to work on an empty stomach, only to be received by the sneers of his fellow workers. ${ }^{45}$

39 The importance of the family in regard to food preparation can also be shown by the fact that Margriet and Libelle photographed all their meals in large dishes, as a homely family meal, in contrast to current fashion (photographing single servings). Furthermore, many food adverts in the 1950s and 1960 s used children to tap into housewives' feeling of responsibility, and to remind her of her duty to take proper care of her offspring.

40 Trude C. M. KNIJN, Carla M. L. H. VERHEIJEN, Moederschap in een Vrouwenblad..., p. 36. The quote is about Margriet c. 1960.

411970 is summed up by the word "nurturing". Ibid., p. 125.

42 Although meal preparation was still among their favourite tasks, by 1984 the appreciation for it had lessened somewhat. De Nederlandse Huisvrouw..., Aselect Survey, p. 150.

43 Belgian housewives, for instance, also liked to treat their families to the occasional elaborate meal. Peter SCHOLLIERS, Arm en Rijk aan Tafel. Tweehonderd Jaar Eetcultuur in België [The Poor and the Rich at the Table. Two Hundred Years of Food Culture in Belgium] (Brussels, 1993), pp. 169-172.

${ }^{44}$ Professional culinary skill, however, was and is associated with men. The editors of Libelle handle this as follows in their recipe column: "And now a recipe for nasi goreng from a Libelle reader. His hobby is cooking and he apologizes a little for this fact. But, aren't all the best chefs men?". Libelle, 1-15-1950 (\#3) p. 91.

45 Trude C. M. KNIJN, Carla M. L. H. VERHEIJEN, Moederschap in een Vrouwenblad..., p. 66. Taken from Libelle \#41 of 1970. 
Preparing meals proved a sizable task. In 1953 American research concluded that if a housewife were to produce everything herself (including baking bread, et cetera) food preparation would take her 5.5 hours a day. By using only "ready-to-serve meals", she could reduce that number to 1.6 hours. ${ }^{46}$ Some manufacturers must have seen this as a marketing opportunity. Why not alleviate the housewife's burden by providing her with ready meals?

Because of ever-greater prosperity, many new products entered the Dutch market in the 1950s and 1960s. Ready meals were prominent among these new goods, causing some to speak of a "wave of convenience" crashing upon Dutch shores. ${ }^{47}$ Companies called Conimex, Koenvisser, Norica, Olba, and Ras advertised throughout the 1950s, recommending a multifarious collection of canned and jarred meals: nasi and bami goreng, spaghetti, macaroni, pilaf and even the "Dutch" combination of potatoes, garden peas and ham. Frozen meals were available as well (although relatively expensive) from the 1950s onwards, most of them produced by Vita, a brand that was bought in 1958 by multinational Unilever and renamed Iglo in $1960 .{ }^{48}$ However, ready meals were troubling products. Previously mentioned imagery showing the ideal woman as a hard worker who took proper care of her family left its mark in Dutch households. Inhibitions regarding convenience greatly influenced housewives during the 1950s and 1960s. ${ }^{49}$

Semi-prepared goods did not cause any problems. Using a bouillon cube or some ketchup for spicing up a sauce was not looked down upon. Taken from Libelle (1960): "For working women, single men, for whenever someone drops by unexpectedly or when you just want to save time, these little packets, cans and boxes can form a solution".50 But scooping an entire meal from a can? That contradicted the image of the ideal woman. A housewife that cut corners in such a matter could be considered lazy: where was her "sacrifice"?

Although advertisers attempted to play on the emotions of housewives, one might say that the texts and images used to commend ready meals did not correspond to the complex feelings consumers had regarding convenience foods. Advertisers marketed their canned dinners as time-savers with great ease of use:

${ }^{46}$ Annemarie DE KNECHT-VAN EEKELEN, Anneke H. VAN OTTERLOO, "Diffusion of Glass Preserved Food in the Dutch Food Pattern 1945-1995”, in: Martin R. SCHÄRER, Alexander FENTON (eds), Food and Material Culture (East Linton, 1998), p. 238.

${ }^{47}$ During the 1960s. Ileen MONTIJN, Aan Tafel!..., p. 85.

48 Iglo price lists 1965 and 1970, HUAR.

49 In Dutch the term is catchier: "gemakstaboe", borrowed from the article "Gemaksvoeding Kampt met Imagoprobleem" [Convenience Food Suffers Image Problem], which mostly deals with the situation during the 1990s. "Gemaksvoeding Kampt met Imagoprobleem" (author unknown), Voedingsmiddelentechnologie, vol. 23 (1990), p. 73.

${ }^{50}$ Libelle, 2-20-1960 (\#8), p. 90. 
Conimex NASI GORENG or BAHMI, canned and ready-made, which means You get a day off in the kitchen! These are delicious meals that You can serve within 10 minutes. Be sure to always have some "days off” ready in Your pantry! Without a care in the world! Take a few cans with You on a picnic! ${ }^{51}$

Reading this advert carefully, one can conclude that it almost literally tries to sell the housewife a few "days off" in the kitchen. Although there must have been a group of people that wanted to buy a little "freedom", to the average housewife the message resembled an invitation to idleness. A significant reduction of effort might cost the housewife her joy in cooking and play into feelings of guilt. A good partner and mother would never serve canned meals! She happily provided homemade meals and made daily sacrifices for her family. It is plausible that the cited advert by Conimex did speak to the lady of the house in some way, and that she dreamt of having a "day off" in the kitchen now and then. Many housewives did occasionally choose an easier way, illustrated by the fact that many families simply ate bread on Saturdays. The 1954 version of Cornelia J. Wannée's Kookboek van de Amsterdamse Huishoudschool, the leading cookery book at the time, also encouraged housewives to opt for frozen fruits and vegetables, partly because of their "excellent taste". 52 But even on Saturdays, when the housewife was supposedly given a day off in the kitchen, she would usually prepare a homemade soup, containing vegetables and meat, which meant that she still spent quite some time in the kitchen. ${ }^{53}$ Although she did allow herself to take some shortcuts, the housewife hardly granted herself a true "day off" when it came to cooking.

This preconception towards convenience food was not new. Jozien Jobsevan Putten describes the pre-war situation in the Netherlands, when the term "lazy-wives-meal" ("luiewievenkost") referred to a meal that did not cost a lot of time. The negative associations seem obvious, causing the historian to claim that a wife was better off not serving these too frequently, "for the sake of marital peace". ${ }^{44}$ Although Conimex, Koenvisser and others obviously did not recommend their ready meals using the term "luiewievenkost", the average housewife had perhaps connected the dots herself, branding ready meals indecent. Even while camping (a popular pastime in the Netherlands)

${ }^{51}$ Margriet, 7-16-1955 (\#29) p. 11; Libelle, 7-16-1955 (\#29), p. 87.

52 Cornelia J. WANNÉE, Kookboek van de Amsterdamse Huishoudschool [Cookery Book of the School of Home Economics of Amsterdam] (Amsterdam, 1954; 13th ed.), p. 53.

53 About $66 \%$ of the 6000 million litres of soup (!) that the Dutch consumed during the 1960 s was home-made. Babette SLUIJTER, Kijken is Grijpen: Zelfbedieningswinkels, Technische Dynamiek en Boodschappen Doen in Nederland na 1945 [To See is To Buy: The Self Service Store, Technological Dynamism, and Grocery Shopping in the Netherlands post-1945] (Eindhoven, 2007; unpublished dissertation), p. 113.

${ }^{54}$ Jozien JOBSE-VAN PUTTEN, Eenvoudig maar Voedzaam..., p. 368. 
the inhibitions regarding convenience persisted. In a leaflet called "Feeding Campers" (c. 1963), ${ }^{55}$ clear demands are made regarding the daily meals. It reads: "Do not underfeed your children!". ${ }^{6}$ Women are told to try making a stew containing potatoes, beans, cauliflower, carrots, tomatoes and smoked bacon, all on one little gas burner. An elaborate meal was apparently not off the table when cooking outdoors. ${ }^{57}$

Not only did the discomfort regarding convenience and new technology have a history, it also persisted until after the 1960s. Furthermore, as a cultural value it was not inherently Dutch. ${ }^{58}$ American housewives felt a certain unease about Betty Crocker's cake mixes, which were seemingly too convenient. The company redesigned the product so that women needed to add an egg, which gave them "a sense of creative contribution". But for many Americans it was still difficult to accept such "shoddy, careless homemaking". 59 Likewise, in West Germany this "conflict between self-production and the use of industrial products" became evident during the 1950s. According to Michael Wildt, two images of being an accomplished housewife co-existed: either shunning industrial products by putting in the hours, or the exact opposite: embracing modern goods and "managing the household like an engineer". ${ }^{60}$

Even in (current) scholarly texts a certain disapproval of convenience can be discerned. John Germov and Laura Williams criticise the change in mindset that ready-made food can bring about. Contending that cooking has become similar to working an assembly line for some, they warn against what they call "the extension of bureaucratic rationality throughout social life". ${ }^{61}$ Second,

55 A date estimated by using what one might call a "gastronomical-philological" analysis. Because the leaflet deals with tomatoes and spaghetti as if they are quite common, one can assume that it was not published before 1960. According to the Dutch Museum of Communication, the printed phone number and address stem from a time between 1946 and 1965. De Voeding van Kampeerders [The Food of Campers], Voorlichtingsbureau voor de Voeding, Commissie Gezinsvoorlichting \& Stichting Huishoudelijke Voorlichting ten Plattelande (The Hague, c. 1963).

56 Ibid., p. 5.

57 Ibid., p. 9.

${ }^{58}$ Ruth Oldenziel and Albert de la Brùheze, for instance, point toward the fact that Canadian housewives were also hesitant in accepting new (technological) help around this time, because of "a tradition of thrift, prudence, and conservation”. Ruth OLDENZIEL, Albert A. DE LA BRUHÈZE, "Theorizing the Mediation Junction for Technology and Consumption", in: Albert A. DE LA BRUHĖZE, Ruth OLDENZIEL (eds), Manufacturing Technology, Manufacturing Consumers: The Making of Dutch Consumer Society (Amsterdam, 2009), p. 15.

59 Susan MARKS, Finding Betty Crocker: The Secret Life of America's First Lady of Food (New York, NY, 2005), pp. 168-170.

${ }^{60}$ Michael WILDT, "Promise of More. The Rhetoric of (Food) Consumption in a Society Searching for Itself: West Germany in the 1950s", in: Peter SCHOLLIERS (ed.), Food, Drink and Identity: Cooking, Eating and Drinking in Europe since the Middle Ages (Oxford, 2001), pp. 74-75.

61 John GERMOV, Laura WILLIAMS, "Introducing the Social Appetite: Why Do We Need a Sociology of Food and Nutrition?", in: John GERMOV, Laura WILLIAMS (eds), A Sociology of Food..., p. 6. 
Luce Giard, who writes about the "McDonaldisation" (although she uses different terms) of the food pattern:

Industrialisation (of products, tools, and transforming operations) has come along to destroy within domestic space - as it had done first in the workingclass space - the regime of this labour. It introduced there the same schema of parcelling, of standardisation, and of the repetition of tasks. Certainly, it allowed people to save time and decrease one type of fatigue, but this was done in order to give rise to gray, homogeneous, empty time, the time of effortless and joyless boredom. ${ }^{62}$

The housewife who was "born tired" cannot count on Giard's sympathy. She romanticises the preparation of a meal, claiming that traditions are being squashed by those attempting to save time, and the manufacturers that are encouraging them.

Second-wave feminism hit the Netherlands at the end of the 1960s, complicating matters further. Women's rights advocates stated that the housewife's position resembled that of a domestic servant, a situation that had to change. A woman was to be equal to a man, which meant getting out of the house, working, and sharing the burden of taking care of the household between the sexes. But in reality, domestic chores were the source of the appreciation received by housewives. The ideal of a wife and mother, cleaning and cooking without any hassle, clashed with the views of feminists, who felt that such women were pitiful at best. A similar opposition manifested itself in advertisements. Jan van Lieshout writes:

Advertisers preached the gains women had made [having to spend less time housekeeping, JV], but they also had a hard time with it. To sell new, time-saving products, they had to both portray handiwork as old-fashioned, unnecessary, silly and inferior, but on the other hand, they could not afford to act in a derogatory manner towards the traditional task of the housewife. ${ }^{63}$

Many women now felt they had to transcend their occupation as "cattle with a vacuum cleaner" ("stofzuigervee"). This development is observable in various contemporary surveys. Young women were less inclined to use the word "homely" to describe themselves, ${ }^{64}$ and admitted to having a negative

62 Michel DE CERTEAU, Luce GIARD, Pierre MAYOL, The Practice of Everyday Life Vol. 2: Living and Cooking (Minneapolis, MN, 1998), p. 212.

63 Jan VAN LIESHOUT, Het Kan Wel..., p. 52.

${ }^{64}$ In the year 1966. De Onbekende Lezeres: Een Psychologische Benadering Van de Damesbladlezeres [The Unknown Reader: A Psychological Approach to the Women's Magazine Reader], Nederlandse Stichting voor Statistiek (Haarlem, 1966), p. 22. 
opinion of domestic chores. ${ }^{65}$ Still, in 1966, around two-thirds of the readers of women's magazines said that the ideal woman ought to be distinctly "homely". ${ }^{66}$ The changes brought on by the demands of feminists were thus not only gradual, they were also not absolute. Older housewives in particular had problems with the emancipatory tactics of younger women.

However, one can discern a marked change in the women's magazines regarding housekeeping and meal preparation, especially in Margriet. In the second half of the 1960s, readers sent letters complaining about washing the dishes and making the beds without the usual addition that such offers were gladly made towards husband and children.

Editors responded to the new concerns of the housewife. Margriet tells her in a twelve-page article (!) how to cut a few corners while housekeeping. ${ }^{67}$ Libelle, although generally more careful with respect to feminism than Margriet during this period (1965-1970), ${ }^{68}$ tells readers to "go ahead and just do nothing for a little while": "There is loads of stuff that you do not really have to do, regardless of what experts say. Why iron pyjamas or towels?". ${ }^{9}$

Adverts for ready meals responded to societal trends as well:

If you're feeling like that, go on an adventure with Conimex!

When the dramatic moment is reached (and who among us has never had it) where it feels like the entire household is eyeing you and a Rebellious Feminist feeling takes hold of you against the constant making of the beds, the washing up, vacuuming, preparing food and whatnot (see photo)... calmly set your eyes on the cans of Conimex. ${ }^{70}$

The photograph shows a woman puffing up her cheeks, and looking into the lens as if to say: "I've had it up to here". Conimex seems to assume that inhibitions surrounding convenience have ceased; meaning housewives are demanding more time to relax. The manufacturer almost takes on the role of a negotiator between men and women here: if you allow her to open the

${ }^{65}$ Theo B. J. MARCÉ, Het Verbruik van Aardappelen, Brood, Rijst, Peulvruchten en Eetdeegwaren Volgens een Voedingsonderzoek in Nederland bij 2000 Huishoudingen in $1967 \mathrm{t} / \mathrm{m} 1970$ [The Consumption of Potatoes, Bread, Rice, Legumes, and Pasta According to Food Research in the Netherlands with 2000 Households during the years 1967 - 1970] (Wageningen, 1975), p. 69.

${ }^{66}$ De Onbekende Lezeres..., Nederlandse Stichting voor Statistiek, p. 21.

${ }^{67}$ Margriet, 11-13-1965 (\#46), pp. 145-157.

${ }^{68}$ An example taken from Margriet: "Being a housewife. In nine out of ten cases, this means having a 24/7 job... We do not mean to incite you. But we $d o$ want to show those of you who have already been incited which steps they might take”. Margriet, 10-3-1970 (\#42), p. 145.

${ }^{69}$ Libelle, 1-2-1965 (\#1), p. 48.

${ }^{70}$ Margriet, 4-11-1970 (\#15), p. 53. 
occasional Conimex can, she will promise not to complain when it comes to making the beds or washing up. ${ }^{71}$

In a similar fashion, Koenvisser responded to the climate of emancipation:

[...] What do you do when you've been shopping all day and forgot about the time? If you suddenly notice that it's half past five? Then you grab a can of Nasi or Bami Goreng. Made by Koenvisser. [...]. ${ }^{72}$

The adverts illustrate how ready meals were a pre-eminent part of the group of time-saving products. But had inhibitions regarding convenience suddenly disappeared? Were mothers now free to go shopping for as long as they liked?

In fact, these products evoked a conflict of interest among housewives in the 1960s. The idea that preparing these ready meals was either lazy or improper was not easily discarded. Especially in Libelle the hesitant reception of feminist ideas is clearly visible. "IF DUTCH WOMEN REALLY WANT TO WORK SO BADLY, THEY CAN", is what columnist Miep RackéNoordijk tells her readers in 1970. But she is quick to add: "If you ask me she'd have to be crazy, because she'll soon find that she'll have two jobs to do, but it's her choice to make" ${ }^{73}$ Hence housekeeping was seen as a fulltime job, and the husband taking over half of the chores was a notion so alien to this columnist that it did not cross her mind.

The use of gender stereotypes, of which advertisers are often accused, ${ }^{74}$ was rather pervasive in adverts published during the early stages of secondwave feminism. While inhibitions regarding convenience were fiercely fought by producers of ready meals, this was not necessarily influenced by feminism: considering the nature of their products, they had always had to fight this mentality. The idea that women were solely responsible for meal preparation was not contested by any of the manufacturers. ${ }^{75}$

Although women's magazines certainly changed their tone and content during the latter half of the 1960s, the revolutionary nature of this

71 Another Conimex advert: "If you've had it up to here with all the cooking and drudgery (which isn't appreciated anyway, sniffle) and an enormous load of dishes has made you decide to live a kitchen-free life of luxury, calm down. Conimex is here to help break the gruelling routines". Libelle, 6-20-1970 (\#25), p. 13.

72 Libelle, 6-6-1970 (\#23), p. 124; Margriet, 5-16-1970 (\#20), p. 82.

${ }^{73}$ Libelle, 2-28-1970 (\#9), p. 11.

74 Wilbert SCHREURS, Geschiedenis van de Reclame in Nederland, 1870-1990 [A History of Advertising in the Netherlands, 1870 - 1990] (Utrecht, 1989), p. 227.

75 Ciska Binneveld claims that the influence of second-wave feminism on the advertising industry was negligible until 1971. Ciska BINNEVELD, "Dit is Mevrouw Nooitgedacht, Zij Doet de Vaat": Het Maatschappelijk Beeld van de Nederlandse Vrouw in Advertenties in Nederlandse Vrouwenbladen in de Periode 1960-1980 en in 1995 ["This is Mrs. Nooitgedacht, She Does the Dishes": The Social Image of the Dutch Woman in Advertisements in Dutch Women's Magazines in the period 1960 - 1980 and in 1995] (Rotterdam, 1997; unpublished dissertation), p. 38. 
development should not be overstated. The Dutch were still living along traditional lines in many ways. In 1965 around 81\% of women who read Margriet found it improper for a mother with school-going kids to have a job; for men the percentage was $87 \%{ }^{76} \mathrm{~A}$ man asking the father of his bride-to-be for his blessing was the norm, and most considered it desirable for women to remain chaste until marriage. ${ }^{77}$

The stance taken towards household tasks such as meal preparation boiled down to: we are allowed to complain once in a while, but there is no alternative. During the 1960s Margriet and Libelle mostly function as a safe place to let off steam for frustrated women, without much trace of truly subversive messages. Some producers of instant products even played into the discomfort felt by housewives when using their products: "CONFIDENTIAL: This is between the chef and the hostess" ${ }^{78}$ For a while it might have seemed like the inhibitions regarding convenience were wavering, but they endured until after 1970 .

There were two ways to circumvent feelings of guilt. First, women could rely on semi-prepared products. There was no shame in making soup or a sauce from a packet. In fact, Conimex, Koenvisser and Iglo mainly advertised with such products during the 1950s and 1960s. Vita and Iglo never even used their advertising space in Libelle and Margriet to show readers their ready meals. Second, manufacturers tried targeting social groups in which the inhibitions regarding convenience were perhaps less pronounced. In adverts aimed at students ${ }^{79}$ and single men, ${ }^{80}$ a company named Olba claimed their meals could compare with the delicious meals that Mother (capital "M"!) used to make. Another Olba advert dealt with the possibility of unexpected guests: in such cases, the lady of the house might open up some cans. However, the difference between endo- and exo-cuisine ${ }^{81}$ was quite large (and not just in the Netherlands). Because offering guests a well-prepared meal could enhance one's status, a housewife would presumably have felt quite uncomfortable serving outsiders a ready meal.

Evidently, societal rules regarding meal preparation became a little more forgiving at the end of the 1960s. But in 1970, reheating a canned or frozen meal remained a daring move for a housewife who cared about what people

\footnotetext{
76 Taken from a multipart survey among readers, published in Margriet. Margriet, 12-11-1965 (\#50), p. 147.

77 Asking for the blessing of the father-in-law was "a given" according to $84 \%$ of women and $85 \%$ of men. $75 \%$ of women and $64 \%$ of men said "yes" to the question: "Should a woman remain a virgin until marriage?”. Margriet, 10-9-1965 (\#41), pp. 32-46.

${ }^{78}$ Margriet, 12-18-1965 (\#51), p. 27.

${ }^{79}$ Libelle, 7-2-1955 (\#27), p. 31.

${ }^{80}$ Libelle, 9-10-1955 (\#37), p. 95; Margriet, 9-17-1955 (\#38), p. 65.

81 Claude LÉVI-STRAUSS, "The Culinary Triangle", in Carole COUNIHAN, Penny VAN ESTERIK (eds), Food and Culture: A Reader (New York, NY, 1997), p. 30.
} 
thought of her. She continued to be in charge of preparing nutritious meals and taking care of her family. The influence of second-wave feminism was not negligible, and expectations on a household level were gradually relaxing. But inhibitions regarding convenience, especially in the matter of meal preparation, were still firmly in place at the start of the 1970 s. $^{82}$

\section{Nutritional concerns}

In the 1950s and 1960s a woman was almost a housewife by definition, along with being a mother. This meant carrying the responsibility for her family's well-being, by monitoring and preparing what they ate and drank. The health of husband and children lay in the hands of the housewife. During the nineteenth century, the relation between food, hygiene and health had slowly become a pressing matter for the public. Although manufacturers were improving their techniques, practices were often not sanitary. Could products be trusted? Anneke van Otterloo writes:

Inappropriate or even harmful preservatives, such as salicylic acid and hydrogen fluoride, were added on a daily basis. Colorants were happily used to give certain products a better look, for instance in butter (aniline yellow or tar colorant), meat and sausage (nitrite) and preserved fruits (cupric sulphate). ${ }^{83}$

In 1922 the Dutch government implemented the Law of Goods ("Warenwet") and the Meat Inspection Law ("Vleeskeuringswet"), while simultaneously setting up Commodity Inspection Departments and their laboratories. This marked the beginning of effective food control. Recent breakthroughs in chemistry helped the inspectors to prevent the deceiving of customers.

The discovery of vitamins was another moment of significance in Dutch food history. At the end of the nineteenth century some researchers concluded that lack of hygiene was not the only cause of food related diseases. Research carried out in Japan and the Dutch East Indies indicated that people living on a diet of solely white rice suffered from a disease called beriberi, which affected the nervous system (caused by a thiamine deficiency). Not the lack of hygiene, but the lack of an unknown substance in the rice was responsible. Pioneering

82 Victrix's solution was simply denying that their pudding was a processed product: "Does real pudding still exist? And by real, we don't mean: some sort of custard taken from a sober bottle (so bleak!) or quick-pudding (for hasty people!). Of course we don't mean expensive ready-made pudding (too easy!). By real pudding we mean the new Victrix Deluxe pudding. It comes in a packet with garnish and everything [...] Modern and easy, cooked in a jiffy”. Margriet, 3-28-1970 (\#13), p. 61.

83 Anneke H. VAN OTTERLOO, “Nieuwe Producten, Schakels en Regimes 1890-1920” [New Products, Links, and Regimens], in: Johan W. SCHOT et al. (eds), Techniek in Nederland..., p. 258. 
nutrition research in the Dutch East Indies stimulated research on vitamins in the Netherlands after 1918. ${ }^{84}$

Several organisations were founded in the course of the twentieth century, such as the Dutch Institute for Public Nutrition ("Nederlands Instituut voor de Volksvoeding", 1919) and the Central Institute for Food Research ("Centraal Instituut voor Voedingsonderzoek", 1940). Consumption had definitively become of academic interest. A large part of the current literature on this subject mentions the "pervading ideology of a modern, rational lifestyle" that took root during these years, which can perhaps explain the growing demand for an optimised production process.

During the 1920s and 1930s vitamins and their biochemical composition were discovered, becoming of great interest to scholars and the general public. ${ }^{85}$ It was the Polish biochemist Casimir Funk (1884-1967) who introduced the term "vitamin". For their pioneering work on vitamins the Dutchman Christaan Eikman and the Englishman Frederic Hopkins jointly received the Nobel Prize in $1929 .{ }^{86}$

The Dutch had appreciated the importance of a nutritious meal before these decades, but the discovery of vitamins made clear that people had often been wrong about what was to be considered healthy. Especially in rural areas the norm for a good meal came down to large amounts of food with plenty of gravy. Raw vegetables were considered rabbit food by many, a notion that slowly changed after various discoveries regarding nutrition. People started assigning "virtually magical qualities" to vitamins and minerals. ${ }^{87}$ The discourse on vitamins was very much an international phenomenon, as was the publicity surrounding the many discoveries made by food experts throughout the twentieth century.

But the attention paid to vitamins and nutrition was not just a scholarly pursuit. Food education changed and intensified; workshops were set up, informing the population at large about new dietary knowledge. The Dutch Association of Housewives ("Nederlandse Vereniging van Huisvrouwen", 1912) and home economics educators played an important role. In their eyes

\footnotetext{
${ }^{84}$ Ruud J. J. HERMUS, "Honderd Jaar Voedingswetenschappen: Het Ontstaan van een Nieuwe Discipline" [A Hundred Years of Food Science: The Emergence of a New Discipline], in: Adel P. DEN HARTOG (ed.), De Voeding van Nederland in de Twintigste Eeuw, (Wageningen, 2001), pp. 23-25.

85 Anneke H. VAN OTTERLOO, "Ingrediënten, Toevoegingen en Transformatie: Heil en Onheil" [Ingredients, Additives and Transformation: Pros and Cons], in: J. W. SCHOT et al. (eds), Techniek in Nederland..., p. 300.

${ }^{86}$ Ruud J. J. HERMUS, “Honderd Jaar...”, p. 23.

${ }^{87}$ Adel P. DEN HARTOG, G. J. BOS, P. A. FLACH, N. G. A. VAN SOLINGEN, "85 jaar Voedingsmiddelenadvertenties in Nederlandse Tijdschriften" [85 Years of Food Advertisements in Dutch Magazines], in: Annemarie DE KNECHT-VAN EEKELEN, Marianne STASSE-WOLTHUIS (eds), Voeding in onze Samenleving in Cultuurhistorisch Perspectief (Alphen aan de Rijn, 1987), p. 147.
} 
it was essential that everyone knew about such matters as the beneficial effects of shorter cooking times and the detrimental effects of sugar.

The average wartime diet underlined the importance of nutrition education, which remained lively during the 1950s. Founded in 1941, the Bureau of Nutrition Education ("Voorlichtingsbureau voor de Voeding") employed mass media to inform housewives about nutrition. The "Schijf van Vijf" (a concept similar to the American "Basic Seven") was introduced in $1953 .{ }^{88}$ A radio program called "Well, Well, Well, What Shall We Eat?" (Tsja, Tsja, Tsja, Wat Zullen We Eten?") informed listeners on what vegetables to buy and how to prepare them. It was produced by the Central Bureau for Horticultural Auctions ("Centraal Bureau voor de Tuinbouwveilingen"), which also advertised in Libelle and Margriet. This bureau had already started a long-lasting advertisement campaign in 1924 with the large-scale distribution of posters and booklets encouraging the consumption of fruit and vegetables. ${ }^{89}$ One of these adverts shows a baby sitting on top of tons of fresh vegetables, accompanied by the following text:

\section{Baby demonstrates.}

Strained vegetables - the first expansion of baby's diet, as prescribed by your doctor - are worth their weight in gold. [...] Why not let your whole household fully enjoy lovely fresh greens: serve a bowl of healthiness every day. Fresh vegetables are full of all those precious vitamins and minerals, which everyone needs in order to stay fit and healthy, whether they're young or old.

It's vegetables that make the difference $!^{90}$

The message is clear: pay heed to nutrition! The boundary between objective food education and commercial advertising proved muddy at times, a troubling development illustrated as well by the fact that doctors' advice was frequently employed to sell products. ${ }^{91}$ Such messages clearly responded to prevailing sentiments. The housewife was held solely responsible for the health of her household, which producers addressed over and over again. The heightened attention paid to nutrition did not lessen during the 1960s (along with a growing attention to being slim, a product of these decades too); one can even

${ }^{88}$ Adel P. DEN HARTOG, "Nutrition Education in Times of Food Shortages and Hunger: War and Occupation in the Netherlands, 1939-1945", in: Ina ZWEINIGER-BARGIELOWSKA, Rachel DUFFETT, Alain DROUARD (eds), Food and War in Twentieth Century Europe (Farnham, 2011), pp. 195-196.

${ }^{89}$ Adel P. DEN HARTOG, "The Changing Place of Vegetables in Dutch Food Culture: The Role of Marketing and Nutritional Sciences 1850-1990", Food \& History, vol.2, no. 2 (2004), pp. 94-96.

${ }^{90}$ Libelle, 7-28-1950 (\#30) p. 45; Margriet, 7-22-1950 (\#29), p. 14.

${ }^{91}$ Anneke H. VAN OTTERLOO, Eten en Eetlust..., pp. 165-166. 
say that it still exists today. From 1961 to 1975 about 33\% of all Dutch food adverts contained some sort of health claim. ${ }^{92}$

The fact that all these warnings and suggestions had their effect should not come as a surprise. Housewives were informed and became convinced. When they entered supermarkets and grocery stores they looked for products that seemed nutritious to them. Hence a healthy image became vital to manufacturers in countries such as the Netherlands, the United States and elsewhere. ${ }^{93}$ It is therefore no wonder that in the 1950s and 1960s manufacturers of preserved goods attempted to create an atmosphere of freshness and healthiness around their products, to repeatedly reassure the housewife. Jonker Fris, a producer of canned vegetables, advertised in Libelle and Margriet, attempting to create such a healthy image. An advert for green beans and garden peas stemming from 1950 mentions that "the vegetables are processed very rapidly so that nothing, and we mean nothing, of their precious taste and nutritional value is lost". ${ }^{4}$ And that same year: "The process is monitored carefully from beginning to end [...] Everything happens hygienically and rapidly, in order to retain $100 \%$ of the aroma and the taste of the vegetables. ${ }^{95}$ It would appear that these canned vegetables were not perceived as fresh, causing the manufacturer to stress that nutritional benefits were preserved multiple times.

In the year 1980, a survey was held among housewives regarding their food choices. Although this study was conducted ten years after the period covered in this article, its results are too significant to ignore. While $44 \%$ of women claimed to pay "a lot of attention" to price, and 53\% said they paid "a lot of attention" to the preferences of their husband and children, $91 \%$ of them stated that they paid "a lot of attention" to the freshness of a product. ${ }^{96}$ While this survey did not take place during the 1950s or 1960s, one can presume that perceived freshness was similarly important to Dutch housewives during these decades.

Especially for a company such as Ras, which freeze-dried their potatoes into powder, these perceptions were cause for concern. How could a process such as freeze-drying retain the nutritional value of potatoes and vegetables?

92 Adel P. DEN HARTOG, G. J. BOS, P. A. FLACH, N. G. A. VAN SOLINGEN, " 85 jaar Voedingsmiddelenadvertenties...", p. 150. Rob Pikaar establishes that $22 \%$ of food adverts printed in Margriet from 1952 to 1954 makes claims regarding nutrition. Rob PIKAAR, "Dàt is Gezonde Voeding", p. 64.

${ }^{93}$ In the United States the sudden popularity of kosher food after World War II proved that food consumption could partially be dependent on its perceived nutritional value. Kenneth F. KIPLE, $A$ Moveable Feast..., p. 270. According to Alan Warde, similar developments marked British consumption choices, albeit significantly later. Alan WARDE, Consumption, Food \& Taste..., pp. 79-80.

${ }^{94}$ Libelle, 11-3-1950 (\#44), p. 43.

${ }^{95}$ Libelle, 11-10-1950 (\#45), p. 19.

${ }^{96}$ Data taken from: Catherine SALZMAN, “Margriet's Advies...”, p. 22. Salzman herself cites: "Menucensus 1980: Buitenshuis Werkende Huisvrouw Neemt Aparte Plaats in" [Menu Census 1980: Housewife Working Out of the Home Deviates], Voedingsinformatie, vol. 8 (1980), pp. 27-28. 
In their adverts, Ras tried to respond to such scepticism. An example taken from 1960:

Ras Instant mashes. Little Ras dinners are ready in no time. Mashed potatoes, carrot and onion-mash, kale-mash, spinach- and apple mash. Cooked, in a dry state. A little milk, water, a source of heat... And after only a couple a minutes, the feast can begin!

$\rightarrow$ Vitamins!

Ras mashes are made using a new procedure that retains all the flavours and the vitamins (C, B1, and B2). Nutritious, good food! [... $]^{97}$

The stress on the nutritional value of these mashes clearly shows the influence of the discourse on vitamins. Furthermore, possible concerns about the "new procedure" are addressed: flavour and vitamins are fully preserved in this product. In the advert, a photograph of a happy housewife amidst heaps of recognisable fresh vegetables is shown, thereby reducing the gap between the modern freeze-dried powders and traditional products.

The advert shows how manufacturers of non-fresh products struggled with presenting their food. Matters were made worse by suppliers of fresh vegetables that advertised in the same women's magazines: "Every day a dose of 'outside' on your plate [...] Because what tastes better than freshness?". ${ }^{98}$ Editors were equally unhelpful in showing the "right" way. At the end of the 1960s, the housewife gained "permission" to take a few shortcuts (a packet, a can) while cooking. But still, however simple some of these recipes were, the focus on nutrition was relentless. Reservations regarding processed foods remained, as demonstrated here in Margriet's recipe section (1970):

Soup from a packet has very little nutritional value, which means it is wise to add a few things. Noodle, chicken or vegetable soup becomes more personal when you add a few pieces of tomato. Little meat balls, canned ones if necessary, are great in almost all soups, while bacon makes your tomato, leek, or oxtail soup more nutritious and more tasty. And don't forget fresh parsley! Surely there is a glass of water containing a little parsley on your sink??9

Starting with the reassurance that a busy housewife can rely on soup from a package every once in a while, the article quickly points towards complications. According to the cited passage, some extra vegetables are considered

${ }_{97}$ Margriet, 12-17-1960 (\#51), p. 87; Libelle, 11-26-1960 (\#48), p. 82.

${ }^{98}$ Libelle, 9-19-1970 (\#38), p. 17.

${ }^{99}$ Margriet, 3-14-1970 (\#11), p. 20. 
"wise", the soup needs more "nutritional value" and should ideally be made more "nutritious".

Throughout the volumes of Margriet and Libelle nothing positive is said about meals that are entirely ready-made. Semi-prepared foods were considered acceptable, but adding nothing to canned and frozen foods seemed downright unhealthy. The aforementioned inhibitions regarding convenience and concerns with respect to health touch in a very meaningful way. If a housewife wants her family to eat well, she should spend plenty of time and effort on preparing meals. But even when making this sacrifice, she must not forget to concern herself with "nutritional value", "vitamins", "health", "freshness", et cetera.

Such advice was to be found everywhere: adverts, cooking columns, and the previously mentioned organisations all tried to explain to the housewife what really mattered when it came to nutrition. If one takes into account the contradictory nature of all these messages, then it is hard to imagine housewives gaining real insight into the matter. For instance, in 1952 renowned nutritionist Barend C. P. Jansen warned producers of preserved foods that:

[...] Many vitamins do not withstand high temperatures (especially above 100 degrees Celsius), as occur while "canning", but are resistant against temperatures below zero degrees Celsius, a temperature at which bacteria and mould causing deterioration can no longer operate. ${ }^{100}$

The quoted passage is also an argument for a transition from canning to deepfreezing as a preservation method. The author even warns that bad preservation methods might cause diseases stemming from deficiencies. ${ }^{101}$

In 1960 a Dutch consumer guide reported on a conference regarding canning. Again scientific research was used as a source of information, but this time conclusions were positive. The School of Agriculture (now Wageningen University and Research Centre) addressed the question of whether canned preserves were healthy, and concluded:

[...] that manufacturers received their products in the shortest possible time, and that it was very fresh when it arrived, while the procedures were also done under the most favourable of circumstances: quick and hygienic. $[\ldots]$ According to them, there was [...] no reason whatsoever to doubt the nutritional value of canned products. ${ }^{102}$

${ }^{100}$ Barend C. P. JANSEN, "Het Conserveren van Voedingsmiddelen in het Licht van de Moderne Voedingsleer" [The Conservation of Food Products in the Context of Modern Food Science], Conserva, vol.1 (1952), p. 84. Barend C. P. Jansen was an internationally known nutritionist who helped discovering the chemical formula of thiamine.

${ }^{101} \mathrm{Ibid}$. . p. 84.

102 "Het Conservenblikje 150 jaar ..." [Tinned Foods, 150 Years...](Editorial), Consumentengids, vol. 8 (1960), p. 6. 
The fact that scholars entered the debate about vitamins in canned goods did not necessarily make matters less complicated. Not everything that was being said about canned preserves was negative, but it does seem that it must have been hard to make any sense of the many (national and international) studies. Claims made were both diverse and inconsistent. ${ }^{103}$

The editorial stance of women's magazines and the opinion of the population regarding preserved food were less ambiguous. Especially Libelle took a firm position, mostly by way of the columns of Martine Wittop-Koning (1870-1963). This well-known food expert was always looking for rational and practical ways of improving nutrition. The loss of vitamins meant that preserving food at home was not an option for her. ${ }^{104}$ Her columns make no mention of industrially manufactured preserves, but it seems obvious that Wittop-Koning was not a fan. After she passed away (1963) Libelle kept on popularising dietetics. A rational, modern view predominated: raw vegetables, less fat, shorter cooking times: "You are cooking just like your mother did... but is that the right way? Dare to change your habits when it's beneficial". 105

Because "chilled" products did not yet exist during the 1950s and 1960s, ready meals were always preserved by freeze-drying, canning, jarring, or deepfreezing. The image of preserves did not get any better in the Netherlands during this period. Besides doubts about their nutritional value, part of the population mistrusted the modern techniques that were being used. What happened in these factories? Who was supervising? As Ileen Montijn writes, "They, the makers of modern food, are anonymous and unreachable, while at the same time responsible for that which keep us alive. Are they to be trusted?"106 Luce Giard expands on that thought: "Modernisation always brings along a certain number of suspicions with it about the quality of products; standardisation, prewrapping, all the modern procedures in food presentation worry people". ${ }^{107}$

These suspicions must have existed before the Second World War, considering the discourse on vitamins during the Depression Era. But it was only when people from all layers of society could afford to eat canned goods every once in a while, that the described distrust towards processed foods really came to the fore. Scholarly literature occasionally mentions the worries consumers were dealing with regarding canned goods: a presumed lack of vitamins, the

103 A few non-Dutch studies are mentioned in: Shane HAMILTON, "The Economies and Conveniences of Modern-Day Living: Frozen Foods and Mass Marketing, 1945-1965”, The Business History Review, vol. 77 (2003), p. 46.

${ }^{104}$ Libelle, 6-16-1950 (\#24), p. 48.

${ }^{105}$ Libelle, 4-9-1960 (\#15), p. 121.

106 Ileen MONTIJN, Aan Tafel!..., p. 35.

${ }^{107}$ Michel DE CERTEAU, Luce GIARD, Pierre MAYOL, The Practice..., p. 75. 
metal having an influence on the taste and colour of the food, and even being poisoned by the contents. ${ }^{108}$

Manufacturers of ready meals did respond to these worries in their adverts. Ras, producer of freeze-dried mashes, and Jonker Fris, manufacturer of canned vegetables, have already been mentioned. These adverts dealt with the nutritional value, but went into the procedure itself as well. "Modern" could mean better: efficient, quick and hygienic.

Margriet and Libelle also contained adverts that spoke for the entire canning industry. "Happy with cans" was the title of these adverts, and their focus was not only on ease of use, but also on the healthiness of using canned goods. The adverts took up a whole page and were placed in multiple editions of Libelle and Margriet in 1970:

Happy with cans.

When in the morning sandwiches are made in a jiffy, and dinner sets tongues tasting and wagging, and you feel like you've earned a nice beer... then, with all this cosiness and all this comfort, you realise that cans make life easier. Day in, day out.

Fanny Blankers-Koen, an Olympic gold medal, leader of the national ladies athletic team. Is she happy with cans?

"Definitely", Fanny says, "I know how essential proper nutrition is, that is why at home we often eat vegetables from a can. It tastes good and it's healthy. And it's full of vitamins (didn't you know?)"109

Multiple interviewees point toward the retention of vitamins. In Fanny Blankers-Koen's subtle "Didn't you know?" one could, with some imagination, read the long history of image building and frustration of the canning industry. As one might have guessed, the situation had not changed in 1970. The Dutch housewife was not convinced; only a small part of the population was buying canned products. ${ }^{110}$

There are other preservation methods besides canning to consider. Ready meals were available in jars too, and eventually in frozen form. The prevailing suspicion towards canned goods among the Dutch population might explain

108 Annemarie DE KNECHT-VAN EEKELEN, Anneke H. VAN OTTERLOO, "Diffusion of Glass..., p. 239. By the 1950s, cans were coated to prevent a metallic taste, but for a long time cans did taste of tin. Adel P. DEN HARTOG, Albert A. DE LA BRUHÈZE, "Verpakking” [Packaging], in: Johan W. SCHOT et al. (eds), Techniek in Nederland..., p. 326.

${ }^{109}$ Margriet, 12-12-1970 (\#51) p. 65; Libelle, 9-12-1970 (\#37), p. 37.

${ }^{110}$ From 1950 to $19541.3 \%$ of all fruit is sold in a can. For vegetables the percentage is $1.2 \%$; for fish it is $0.3 \%$. From 1960 to 1964 (respectively) 2.0\%, 1.9\% and 0.5\%. From 1970 to 1974 (respectively) $2.1 \%, 3.1 \%$ and $0.5 \%$. Annemarie DE KNECHT-VAN EEKELEN, Anneke H. VAN OTTERLOO, “Diffusion of Glass...”, p. 233. 
the relative success of the jarring industry. A company called Hak was successful in selling jars of vegetables and fruits, eventually conquering $21 \%$ of the canning market by 1970 . Perhaps the positive image of jarred foods explains the relative success of Hak, since the prices of their products were generally higher than with most canned counterparts, whereas taste and nutritional value remained roughly the same. ${ }^{11}$

Furthermore, the success of food in jars can possibly be explained by looking at the type of arguments used in their adverts. Ready meals in a jar, such as those produced by Conimex, were hardly ever advertised in Margriet and Libelle. But Hak did advertise in these magazines, ${ }^{112}$ as did the jarring industry in general. In the latter adverts jarring was praised without the mention of any specific brand:

As clear and pure as glass.

[...] Who is responsible for the cosiness within the household, serving all sorts of delicious products in the home and on the table? It's you, the lady of the house. [...] Jars are ideal. Pure and clear, clean and hygienic. Plus, glass is honest: You'll be able to see what and how much you are buying, and in glass everything always stays fresh.

SEE WHAT YOU'RE BUYING: MAKE SURE IT'S GLASS! ${ }^{113}$

One might say that the advert above calls upon the emotions of the housewife. It was designed to work on a psychological level, employing words such as "pure" and "honest" to win trust. Without mentioning cans, the text creates a diametrical opposition between cans and jars, using the exact characteristic that cans will never be able to offer: a look inside. Until bought, the contents of a can remain a mystery, which is only a problem, of course, if its producers are not entirely trusted by the consumer. Although the Hak company was doing quite well in the Netherlands, it still only produced $21 \%$ of a market which was rather small in itself. Perhaps the higher price of jarred goods kept the industry from making a real breakthrough on the preserved goods market.

The history of frozen meals is different. The range of products in this category broadened during the 1960s, but sadly manufacturers of frozen meals (Vita, Iglo, Conimex) barely advertised these dishes. Sales numbers were a disappointment, both immediately after the war and during the 1950s and 1960 s. Even by 1980 no less than $92 \%$ of all housewives claimed to "never" buy

${ }^{111}$ Ibid., pp. 232, 230.

112 Margriet, 1-10-1970 (\#2), p. 10; Libelle, 1-31-1970 (\#5), p. 5.

113 At the bottom of the advert in capital letters: Publication by the Joint Glass factories of Schiedam (“Vereenigde Glasfabrieken Schiedam”). Libelle, 4-17-1965 (\#16), p. 14. 
frozen meals. ${ }^{114}$ At multinational Unilever, some were convinced that cultural values were to blame:

The difficulty is [...] that the Dutch housewife is very conservative and will always want the fresh product, even when someone tells her that she'll spend less when buying the frozen variety (e.g. apple sauce). ${ }^{115}$

However, other factors were also at play. An advert by Vita, published in 1960, shows a mother telling her little girl a story. The accompanying text reads:

Vita.

Almost time for dinner... but still some free time for a little story-telling!

Oh, I'm not a magician. But telling a story while preparing a delicious meal... That I can do! Because I've discovered how wonderful it is to eat Vita frozen vegetables a few times a week. Truly ideal; delightfully fresh and... already neatly cleaned. Look at that little girl enjoying her meal. And my husband? He thinks it's a treat! [...]

Fresh! Healthy! Already cleaned! All year round!

A packet of Vita frozen food that is bought today, can easily be stored until tomorrow! $!^{116}$

Before going into problems regarding frozen meals, it must be stressed that in the total advert, the word "fresh" is used three times. The general message of the text is mostly about nutrition and health, matters that have already been dealt with in this article. What is important for the current argument is the last sentence of the advert: in the year 1960, most housewives could not store Vita products for more than a day. Hence frozen meals were preserved goods that most people were not able to preserve in any meaningful way. Another practical obstacle holding back sales was the relatively high price of frozen meals.

A more "cultural" explanation for the lack of success, apart from the aforementioned "conservative" housewives, can perhaps be found in certain problems regarding the image of frozen foods. An employee of Vita explains:

Freezing food had a bad reputation then. People connected deep freezing $[\ldots]$ to freezing products in the night frost, which turned them to mush, and with the poor quality of frozen meats from Argentina. ${ }^{117}$

\footnotetext{
${ }^{114}$ Catherine SALZMAN, “Margriet's Advies..., p. 22.

115 Hans BUITER, "Koelen en Vriezen”, p. 348.

116 Libelle, 2-6-1960 (\#6) p. 76; Margriet, 2-13-1960 (\#7), p. 38.

${ }^{117}$ Hans BUITER, “Koelen en Vriezen”, p. 345.
} 
The cited passage references slow freezing methods, which caused ice crystals to form inside meats and vegetables, ruining the structure of such foods when thawed. Whether frozen meals were more nutritious than their canned or jarred counterparts at this point in history remains doubtful as well. ${ }^{118}$

Taking into account the fact that vitamins and nutrition became ever more important in the Netherlands during the 1950s and 1960s, it is no wonder that people critically examined the nutritional value of a variety of (new) products. The fact that processed foods and especially ready meals took a few blows was partly a trust issue. The true nutritional value of these meals, whether it was nasi goreng from a can or frozen mashed potatoes with cod, surely left something to be desired. But it is important not to underestimate the influence of certain negative images existing among the Dutch populace.

The cited adverts show the answer that manufacturers came up with: a continuous stream of reassurances regarding nutritional value and the amount of vitamins. And despite the fact that imagery was not the only factor influencing the sales of preserved foods, it is clear that unfavourable perceptions must have been prolonged and ubiquitous, partly because of the continuous focus on the importance of proper nutrition. Taking into consideration that on top of that, the horticultural sector published advertisements for their fresh spinach and fresh cauliflower, one can see why ready meals had a very hard time competing during these decades.

\section{Conclusion}

Concluding that cultural values influenced food choices during the 1950s and 1960 s seems inevitable. However, these values should be placed within their historical context. The aforementioned inhibitions regarding convenience were not an invention of the 1950s, but they did gain prominence by post-war developments. Sacrifice was idealised; the average housewife did not complain, and proudly felt that she contributed to the reconstruction of her country. Similarly, the discourse on vitamins might have stemmed from pre-war decades, but the stress on the importance of nutrition was ceaseless during the 1950 s and 1960s. Housewives were constantly reminded of the importance of healthy food. At first by pioneers such as Martine Wittop-Koning, but from 1941 onwards also by the Bureau of Nutrition Education, which as the focal point of nationwide nutrition education published a significant amount of

118 Multiple contemporary studies drew negative conclusions about the nutritional value of frozen ready meals. A few examples can be found in: M. A. VAN DER MEER, J. B. LASSCHE, C. N. PASCHA, Diepuriesmaaltijden..., pp. 5-6. 
material on the matter. Naturally, some advertisers also had their own message when it came to nutrition.

The ready meal suffered. In fact, it could almost be seen as an anachronism during these decades. Technologically and economically, the 1950s and 1960s were an era of enormous progress, but the cultural values dominant in Dutch society and the existent food pattern gave these products a false start. Companies such as Conimex, Heinz and Koenvisser stopped producing their canned meals, Ras gave up on their mashes, Olba had to shut down entirely, and the frozen meals produced by Iglo were unsuccessful pre-1970. Using semi-processed foods was better tailored to the inhibitions regarding convenience, especially once second-wave feminists kindly instructed housewives to keep their cooking simple now and then. Plus, housewives had more control over the nutritional value of a meal if she added some of her own ingredients to a dish, instead of leaving it all to the manufacturer. Although some previously mentioned practical issues, such as supply difficulties and low purchasing power among customers initially influenced the popularity of ready meals as well, these mostly disappeared during the1960s. Only the lack of freezers in Dutch households could be mentioned as a practical factor that still inhibited the sale of ready meals $c .1970$.

The cultural values described did not suddenly disappear around 1970 . Inhibitions regarding convenience slowly dwindled during the 1970s and 1980s. Among the causes were second-wave feminism, (married) women joining the workforce, a rise in single person households and the emergence of the microwave. ${ }^{119}$ Nevertheless, the discomfort regarding convenience food has never entirely gone away in the Netherlands. ${ }^{120}$

Paradoxically, the intake of fatty and sugary foods has been on the rise since the decades discussed, while the importance of proper nutrition is stressed as never before. The health discourse has intensified and been politicised since the 1970s. The imagery surrounding products and their perceived freshness is still essential for determining food choice. ${ }^{121}$ For some ready meals this has had some unwanted consequences, but certain chilled meals, especially those served in steam baskets, have managed to garner a very positive image regarding nutritional value. These meals are touted as healthy, with advertisements

${ }^{119}$ In 1990 about $15 \%$ of Dutch households had a microwave; in 2001 this number had risen to 79\%. Vlees: Cijfers en Trends: Marktverkenning over het Consumptiegedrag in Nederland [Meat: Figures and Trends: Market Research about Consumer Behavior in the Netherlands] (Rijswijk, 2003).

120 "Gemaksvoeding Kampt..., (author unknown), passim.

${ }^{121}$ In the summer of 2011 this once again became clear when Dutch cucumber growers suffered a financial catastrophe because of a scare pertaining to the EHEC-bacterium. Even though horticulturists could rationally prove that their product had been checked rigorously, cucumber sales dropped sharply because of unfavourable imagery and distrust towards modern industrial production methods. See: http://fleishman.nl/2011/06/10/ehec-building-up-a-killer-reputation/?lang=en. Created: June 10th, 2011. Viewed: October 2nd, 2013. 
stressing the amount of vegetables they contain, and their minor loss of vitamins during preparation. ${ }^{122}$

Compared to other countries, the ready meal has proved unpopular in the Netherlands, although demand has grown in recent decades. ${ }^{123}$ Perhaps the current popularity can be explained by the fact that technological progress has improved the organoleptic characteristics of these products, simply making them tastier than their 1950 s and 1960 s predecessors. ${ }^{124}$ It is also plausible that new cultural values play a role. Possibly, ready meals are now seen as "hip" by some, as they have become associated with a successful and busy life.

This article has purposefully operated on a small-scale. Regardless, it would be interesting to see whether the cultural values described can partly be disconnected from the culinary aspect, and to go deeper into the genealogy of these mentalities by looking at their historical context. Some topics have been touched upon, but could gain from expansion. An example: how is the discourse on vitamins related to an anxiety about modernisation? Above all, the current study could prove informative when adding a comparative element, by internationalising its research domain. There seem to be a few clues (of which some can be found in this article) that point to similarities between the Netherlands and other Western countries such as the United States and (West) Germany when it comes to the described cultural values. It is quite plausible, however, that some distinct differences existed between these cultures, hence a thorough analysis would have to be carried out.

Such historical research, examining the influence of cultural values on food choice, is still scarce, especially in the Netherlands, where food historians have generally demonstrated a preference for focussing on economic factors and technological development. Prevailing ideas, cultural values or religious motivations regarding food choices have too often been neglected as possible research topics in and of themselves. While such studies will obviously have their limitations as well, tracing and examining cultural factors is indispensable when aiming to acquire a fuller understanding of the development of twentieth-century food history.

122 However, the meals do not meet the standards of food experts from the Nutrition Centre ("Voedingscentrum"), which once again demonstrates how essential perceptions and imagery can be. Annemarie BARBIER-SCHENK, "Hoe Gezond is Kant-en-klaar?" [How Healthy is Ready-Made?], Voedingsmiddelentechnologie, vol. 40 (2007), p. 20.

123 Jozien JOBSE-VAN PUTTEN, Eenvoudig maar Voedzaam..., p. 431.

${ }^{124}$ See: Vincent HENTZEPETER, "Stoom Afblazen in de Magnetron" [Blowing Off Steam in the Microwave], Voedingsmiddelentechnologie, Vol. 40, No. 9 (2007), pp. 11-12. 
